\title{
Development and Operation Results of Japanese Accent Perception Test BASED ON E-LEARNING SYSTEM
}

\author{
KIM Yu Young \\ Dongduk Women's University, South Korea \\ yuiyu1004@dongduk.ac.kr
}

\begin{abstract}
Main purpose of this study is to find and build a model of Japanese accent perception practice at Japanese lessons in regular classrooms and those based on utilization of network and multimedia. Until now, Japanese phonetic researchers and teachers had to spend a disproportionate amount of time and effort to conduct experiments or test, and to develop the means to process resulting data of the experiments conducted. With the proposed [AJ-phonetic Test] system, accent tests are conducted online. In this respect, Japanese learners can take part in the phonetics experiment in a time and location convenient to them. Also, researchers and teachers can work on the obtained data by using the database available. Moreover, AJ-phonetic test feedbacks provide not only test results but also a more comprehensive data analysis. Results of the 12-year operation of AJ-phonetic test in Korea proved to have a positive effect on students as well as teachers. This paper present general guidelines necessary to conduct the AJ-phonetic test. Firstly, in case of Korean learners of Japanese, a separate set of words accentless pitch and those with accent pitch is needed because the two sets present different difficulty levels for a learner. Secondly, as the number of moras in a word affects the difficulty, we introduced dummy words, which proved successful in controling the level of difficulty and increasing learning effect. Besides, dummy words worked well as a substitute for low tone (frequency) long words as well for long words in general. Thirdly, since there are only few cases with a distinctive long-short opposition in Korean, Korean learners of Japanese have difficulties recognizing accents in words with special moras. Such words therefore need special attention. Finally, the ability of Korean learners of Japanese to recognize accent in Japanese words differs based of the learners' native dialects. Best results were obtained by learners from the Jeonlado region, followed by those from Gyeongsang-do region, while learners from Seoul had most difficulties in recognizing the accent. From all the above findings we conclude that Japanese accent education is highly necessary, and that in the process of education, both Japanese accent characteristics as well as learners' native dialects should be considered.
\end{abstract}

Keywords: e-learning; online test; Tokyo word accent; Japanese word accent exercises; Japanese word accent teaching

Acta Linguistica Asiatica, 10(1), 2020.

ISSN: 2232-3317, http://revije.ff.uni-lj.si/ala/

DOI: 10.4312/ala.10.1.67-86 


\section{Povzetek}

Glavni namen študije je oblikovati model za utrjevanje zaznavanja japonskega besednega naglasa pri vajah japonščine $v$ klasičnih učilnicah kot tudi $v$ učilnicah, ki temeljijo na uporabi spleta in multimedijev. Do zdaj so morali raziskovalci in učitelji japonske fonetike porabiti nesorazmerno veliko časa in truda za izvedbo in analizo takšnih raziskav ter da so razvili programe za obdelavo rezultatov. S predlaganim sistemom, t.i. AJ-fonetičnim testom, je naglasne teste mogoče izvajati preko spleta. $V$ tem pogledu lahko japonski učenci sodelujejo $v$ fonetičnem poskusu $v$ času in na kraju, ki jim ustreza. Prav tako lahko raziskovalci in učitelji dostopajo do pridobljene baze podatkov. Povratne informacije iz baze AJ-fonetičnega testa ne vsebujejo samo golih rezultatov temveč tudi celovito analizo podatkov. Rezultati 12-letnega izvajanja AJ-fonetičnega testa v Koreji imajo pozitivni učinek tako na študente kot tudi učitelje. $\checkmark$ tem prispevku so predstavljene splošne smernice, potrebne za izvedbo AJ-fonetičnega preizkusa. Kot prvo je za korejske učence japonskega jezika potrebna ločena obravnava besed brez naglasnega mesta in tistih z naglasnim mestom, saj ta dva sklopa predstavljata različne stopnje zahtevnosti učenca. Drugič, ker dolžina moraičnih enot vpliva na težavnost prepoznavanja besednega naglasa, smo uvedli tudi brezpomenske besede, ki so se izkazale za uspešne pri nadzorovanju stopnje zahtevnosti in povečanju učnega učinka. Poleg tega so brezpomenske besede delovale kot nadomestek za dolge besede izrazito nizkih tonov (frekvenc) ter za besede s strukturno zahtevnejšimi moraičnimi enotami. Tretjič, ker je $v$ korejščini le nekaj izrazitih primerov z opozicijo dolg-kratek glas, imajo korejski učenci japonščine težave pri prepoznavanju naglasa v besedah, ki vsebujejo posebne moraične enote. Takšne besede zato potrebujejo posebno pozornost. Nenazadnje se sposobnost korejskih japonskih učencev, da prepoznajo naglas $v$ japonskih besedah, razlikuje tudi glede njihovo materno narečje. Najboljše rezultate so dosegali učenci iz regije Jeonla-do, sledijo jim tisti iz regije Gyeongsang-do, medtem ko so imeli učenci iz Seula največ težav pri prepoznavanju japonskega besednega naglasa. Iz vseh zgornjih ugotovitev sklepamo, da je potreba po utrjevanju znanja o japosnekm besednem naglasu zelo visoka ter da je v procesu izobraževanja potrebno upoštevati tako japonske naglasne značilnosti kot tudi materno narečje učencev.

Ključne besede: e-učenje; spletni test; tokijski besedni naglas; vaje japonskega besednega naglasa; poučevanje japonskega besednega naglasa

\section{Introduction}

Rosenberg (2000) defined e-learning by proposing three important and fundamental criteria of e-learning. First, e-learning should be able to update, store, distribute, and share training or information through the network immediately to give access to the system for the students' benefit and education. Second, it should be delivered to endusers through computers using HTML based standard Internet technologies readily available to the learners. Third, e-learning should focus on understanding and interpreting learning concepts as learning solutions that go beyond the paradigm of traditional learning methods. Also, Rosenberg (2000) set standards for accessibility that enables learners to access education and information remotely, instructor's immediate feedback to learners, and learning solutions that go beyond the traditional paradigm of learning. However, many present studies, including Rosenberg (2000), focus on the 
criteria of e-learning which aim the development of theories catering learner's perspective. However, we believe that the instructor's perspective is equally important.

Until now, teachers and researchers of Japanese word accents had to spend a large amount of time and effort to conduct Japanese accent tests and processing the result. Above all, instructors who wanted to conduct such practice or tests have had to gather learners in one place so far, but it was a complicated effort to gather learners in one place at one time. Besides, Japanese accent education has limitations on multimedia equipment and test location, which makes it challenging to train with defined and identified limited resources that were meant to be used in a limited schedule of time.

Studies have already shown that for instructors, e-learning should have a comprehensive academic management system that would manage information such as learner's learning history as well as their progress online (e.g., LMS; Learning Management System). This system enables the instructor to give learners appropriate feedback according to their level and previous achievements, while also improving the content of the textbook and adjusting the difficulty according to the learners' understandings and reactions. This system works best by building an automated online test system, whereby instructors can effectively invest much of their time spent on non-education, such as exam submission and grading, collecting and classifying result data. This personalized educational tool enables the instructor to maintain learners' interest in learning, and to reduce the probability of learners becoming frustrated and in a worst scenario dropping out of the program. For all the above reasons, this study developed The Online Tokyo Accent test Program [AJ-phonetic Test].

With the AJ-phonetic test we also wanted to meet the requirements of e-learning from the learners' point of view. Learners who participate in e-learning need feedback and evaluation gauges on the quality and progress, in other words, a device that can maintain a sense of reality about students' learning in general and individually. Much resembling traditional teaching-learning, a learner is not alone when using e-learning platforms. Within the AJ-phonetic Test system, they can always communicate with an instructor about learning contents, and this can be done through communication means such as bulletin boards ( $Q$ and $A$, Freeboard) or e-mail, and likewise, exchange opinions with virtual classmates learning together or working on a same project. Through this virtual community, a learner can eliminate distance from the instructor even within the e-learning system, and experience a sense of peer-to-peer. Thus it can be said that the system is similar to the effect of learning in a traditional teachinglearning system. While learners can overcome spatial and temporal limitations by using the network, where participating in such an education can be adjusted to their schedule, learners can also follow their progress and achievements, which are available in the system anytime. Learners can besides accurately identify their current knowledge and performance, and set learning goals through an objective evaluation 
system and analysis function, which raises learning motivation and consequently boosts learning at all stages.

On the other hand, according to the Japanese Education Association (1991) surveying the learning needs of Japanese learners, learners were more interested in speaking skills than anything else. According to the survey results, 59.0\% of the learners said that among the four functions of writing, reading, listening, and speaking, the speaking function was the most necessary, and about $38.1 \%$ of the learners wanted to be able to speak with natural pronunciation and intonation in the future. This is the second highest response rate, which indicates that many learners strive for fluent and correct pronunciation when learning Japanese.

Among studies on listening ability of Japanese accents, Study Group 3, Comprehensive Study on Japanese Language in the International Society (Osamu Mizutani), which was launched in 1994, was designed to examine the reality of Japanese (Tokyo dialect) accent listening. Ayusawa (1997) found that there was a difference in perceiving Japanese accents according to the student learner's native language differences. Besides, the results of the longitudinal study of Ayusawa, Nishinuma and Kawatsu (2000) Tokyo Accent Listening Test reported that with 24 subjects, including 13 Koreans, the subjects were divided into three groups in the order of the percent correct. In this study, three Korean learners among eight in the upper group, four Korean learners among eight middle-level group, and six Korean learners among eight subgroups, and the longitudinal results showed that most Korean learners placed in the lower middle level group. This represents the necessity and importance of Japanese accent practice such as this study for Korean Japanese learners.

Ogawara (1997) examined the relationship between Korean learner's pronunciation and listening in the study of the student's accent listening ability. As a result, students with better listening ability tended to have a valid listening standard, and that tendency led to the improvement of pronunciation in those learners.

Choi (2006, pp. 200-201) conducted an experiment on how Korean Japanese learners (Seoul and Busan dialect speakers) and Japanese native speakers responded to each other according to the change in the accent position of each word in Japanese. As a result, learners from Seoul who had no accents tended to find similarities in Korean rhyme, rather than feeling Japanese accents in areas where there was a sharp drop in voice. However, the learner from Busan, with an accent, confirmed that he responded similarly to the Japanese native speaker. In other words, there is a difference in the cognitive ability of foreign languages depending on whether there is an accent in the dialect of the place of origin. Moreover, according to Jeong (2009, p. 234), because of interference of the mother tongue Japanese learners of Seoul dialects who do not have Mora, generate and perceive Japanese by syllable units. And most of all, they have a very weak point in their perception of special phonemes. 
The above results suggest that listening tests of Japanese accents with Koreans who are particularly vulnerable to Japanese-accents, can be useful for improving their Japanese proficiency. Therefore, this study intended to develop and operate the Tokyo accent perception test based on the system that meets the criteria of e-learning mentioned above, and then analyze the results.

\section{Research design}

In this study, we considered concepts of e-learning in previous research, and reflect the instructor's perspective necessary for the development of appropriate student elearning strategies. Then, based on the concept of e-learning, we developed an online Tokyo accent test, [The AJ-phonetic test].

It is noted that exchanging high and low tones shape Japanese accent. We designed the AJ-phonetic test by introducing e-learning technology with the aim that learners could practice Japanese accent in regular and multimedia classes, or online. We further analyzed its process and results for 12 years and two months, and revealed our findings on what is needed for future Japanese accent tests and education.

In the following sections, we present specifications of Japanese accent test [AJphonetic Test], details about the experiment design, and detailed features of the AJphonetic test.

\subsection{Technical specifications}

The AJ-phonetic Test (http://www.japanese.or.kr/phonetic_main.aspx) was designed using the Visual Basic.Net / ASP.Net 2.0 and MS-SQL. The basic structure of AJ-phonetic test is presented in Figure 1. 


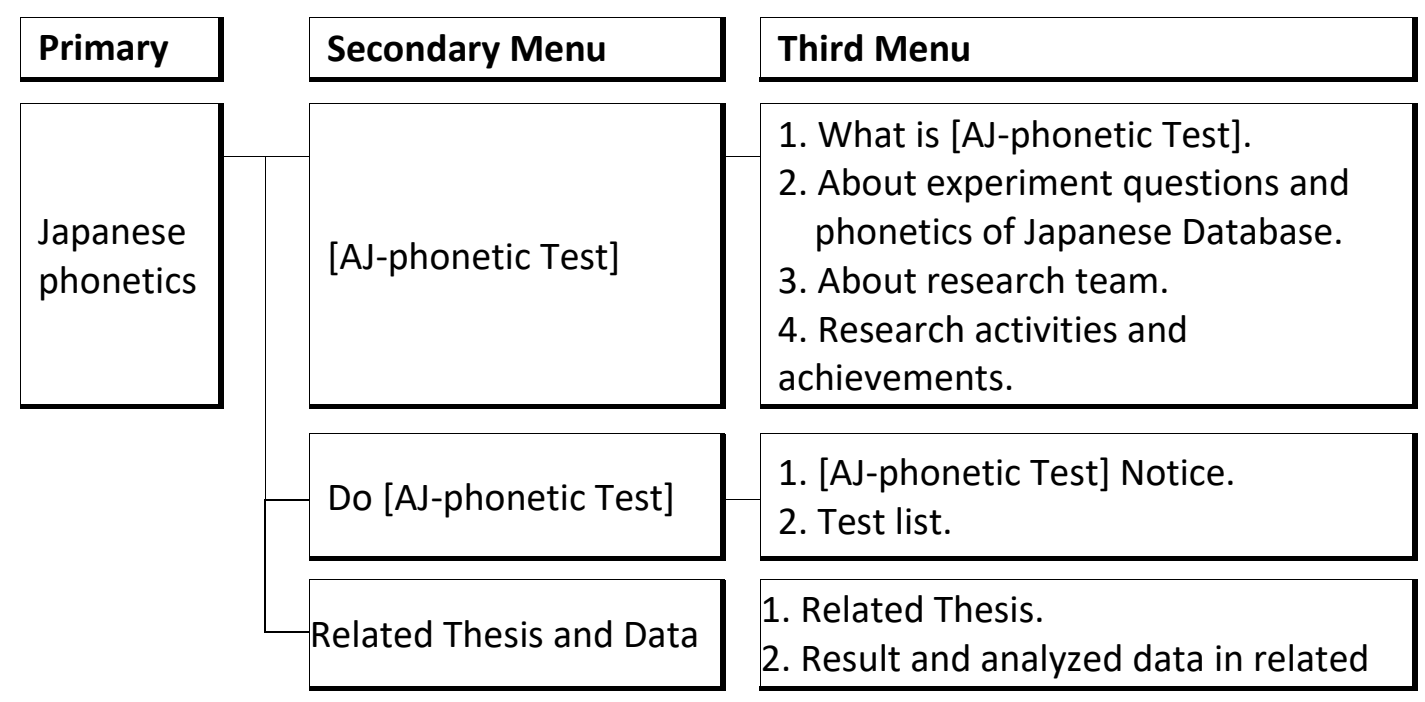

Figure 1: The basic structure of [AJ-phonetic test]

\subsection{Research timeline and participants}

This research started in October 2007 and lasted until December 2018. Throughout the period of 12 years experiments were taken 8094 times.

Altogether 605 participants were Korean native speakers and students of Japanese (1st to 4th graders) from Dongduk Women's University, Duksung Women's University, Korea University and Konkuk University. They have all gone through basic education on types and pronunciation of Japanese accents and are qualified for the Japanese Language Proficiency Test from N4 to N1. This research included the results to the point when the rate of correct answers reached $90 \%$ or above.

\subsection{AJ-phonetic Test and its features}

The AJ-phonetic Test is available at http://www.japanese.or.kr/phonetic_do.aspx. Figure 2 shows an excerpt from this page. 
2. Test list

2-1. All test is need to be logged. If you don't have an Id, please register to $\left.{ }^{\top} \mathrm{AJ}\right\lrcorner$ system.

2-2. Now, register to $\left\ulcorner A J_{\lrcorner}\right.$system and get an ID $\rightarrow-$ Go

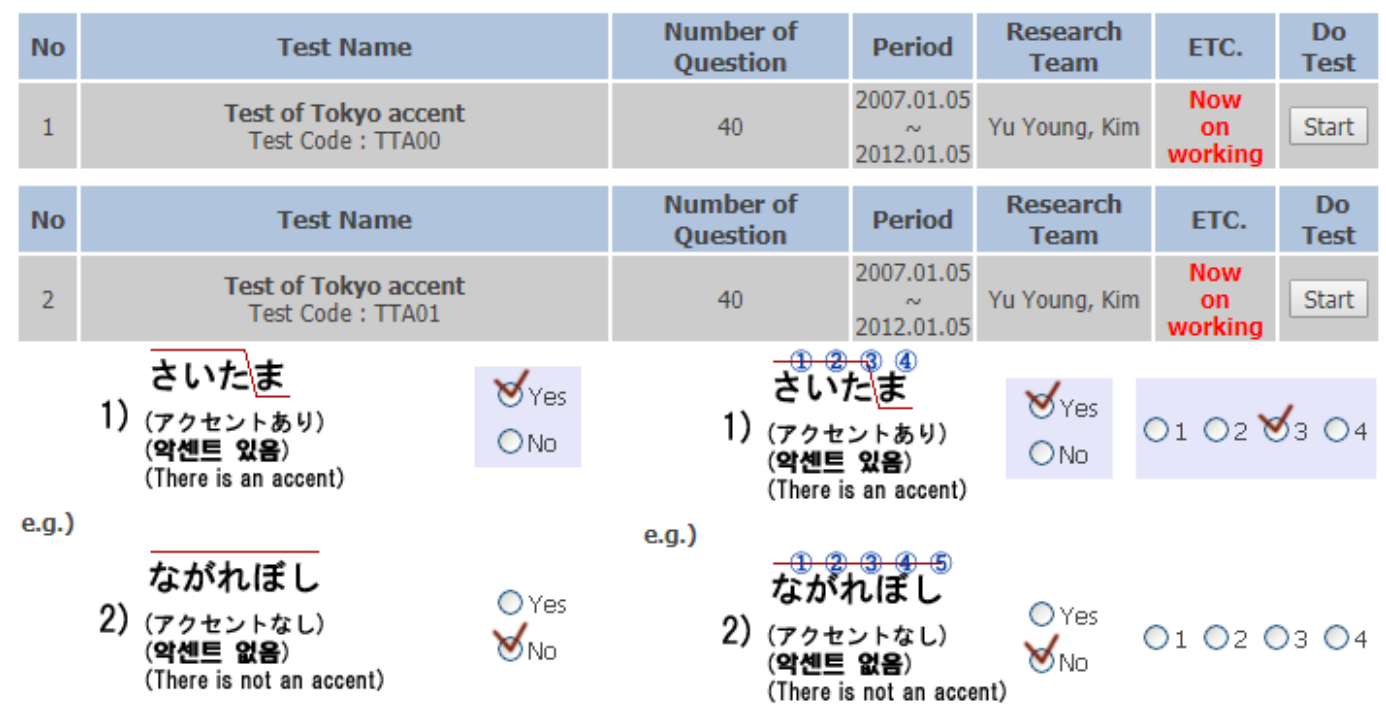

Figure 2: Web page of the AJ-phonetic test

There are four types of tests available on this page. They are presented in the following subsections.

\subsubsection{TTA00 (Test of Tokyo Accent 00)}

TTA00 contains 40 words of two or more moras (2-mora-words: 4 items, 3-morawords: 8 items, 4-mora-words: 12 items/ 5-mora-words: 16 items; see Table 1 for details). Some words are accented and others accentless. Among them are dummy words (e.g., まま,ままま, etc). Participants should check [Yes] when they judge that a word contains accent (phonetically defines as a radical tone drop), or otherwise check the [No] button.

\subsubsection{TTA01 (Test of Tokyo Accent 01)}

TTA01 is structured similarly to TTA00 but with an additional task. Namely, when participants judge that there is an accent (a radical tone drop) and check the [Yes] button, they should also define the location of the accent place (defines as the last high mora before a tone drop). 
Table 1: Word list of TTA00 and TTA01

\begin{tabular}{l|l|l|l|l|l|l|l}
\hline No. & Word & No. & Word & No. & Word & No. & Word \\
\hline 1 & となり & 11 & ままままま & 21 & たからもの & 31 & おしぼり \\
2 & たかとび & 12 & まままま & 22 & おすねもの & 32 & まままま \\
3 & おなまえ & 13 & まままま & 23 & ままままま & 33 & ままままま \\
4 & ままままま & 14 & ままま & 24 & まま & 34 & ながれぼし \\
5 & ねこ & 15 & あなた & 25 & みかいはつ & 35 & だいじころ \\
6 & ままま & 16 & おす & 26 & おととい & 36 & ままままま \\
7 & しごと & 17 & まままま & 27 & まま & 37 & さいたまし \\
8 & まままま & 18 & おしいれ & 28 & まままま & 38 & まままま \\
9 & ままままま & 19 & だいまらい & 29 & ままままま & 39 & ままま \\
10 & みやげもの & 20 & ままままま & 30 & もしもし & 40 & なみだ \\
\hline
\end{tabular}

\subsubsection{TTA02 (Test of Tokyo Accent 02)}

TTA02 contains accented 20 words of the length of two or more moras (2-mora-words: 2 items, 3-mora-words: 4 items, 4-mora-words: 6 items/ 5-mora-words: 8 items; see Table 2 for details). Some of the words are dummies (e.g., まま,ままま, etc).

Table 2: Word list of TTA02

\begin{tabular}{l|l|l|l|l|l|l|l}
\hline No. & Word & No. & Word & No. & Word & No. & Word \\
\hline 1 & たかとび & 6 & ままままま & 11 & ままままま & 16 & おしぼり \\
2 & ままままま & 7 & まままま & 12 & みかいは & 17 & ままままま \\
3 & ねこ & 8 & あなた & 13 & まま & 18 & ながれぼし \\
4 & ままま & 9 & まままま & 14 & ままま & 19 & さいたまし \\
5 & まままま & 10 & だいまらい & 15 & もしまし & 20 & なみだ \\
\hline
\end{tabular}

\subsubsection{TTA03 (Test of Tokyo Accent 03)}

According to Onzuka (2011, p. 247) Korean learners of Japanese have difficulties recognizing the so-called special moras (also called special moraic phonemes in this article). The difficulty of its recognition depends on its word position; most difficulties present a prolonged sound and a syllabic nasal at the word-ending, followed by a midpositioned geminate consonant and a prolonged sound, while a mid-positioned syllabic nasal is relatively easy to recognize.

Words in the TTA03 test were selected in consideration of this difficulty (Table 3). All 32 words contain more than 2 moras. The task, however, is the same as in the previous test. In this test participants checked [Yes] when they judged that there is an 
accent (a radical tone drop), and if clicking so, they further defined the location of the accent place (defines as the last high mora before a tone drop).

Table 3: Words list of TTA03

\begin{tabular}{|c|c|c|c|c|c|c|c|}
\hline No. & Word & No. & Word & No. & Word & No. & Word \\
\hline 1 & しんせつな & 11 & せんもんか & 21 & こうぎ & 31 & おじさん \\
\hline 2 & おおぜい & 12 & へいきんち & 22 & えほん & 32 & ゆっ<り \\
\hline 3 & こつか & 13 & きんにく & 23 & きっぷ & & \\
\hline 4 & さんぽ & 14 & こんど & 24 & そうじ & & \\
\hline 5 & あさって & 15 & よかったら & 25 & おかあさん & & \\
\hline 6 & あんない & 16 & がっこう & 26 & どろぼう & & \\
\hline 7 & みなさん & 17 & すいようび & 27 & ひこうき & & \\
\hline 8 & けっこんしき & 18 & にほんじん & 28 & かっこく & & \\
\hline 9 & アイスティー & 19 & おめでとう & 29 & ふかんぜん & & \\
\hline 10 & きっさてん & 20 & さとう & 30 & たかっけい & & \\
\hline
\end{tabular}

Table 4: Special moraic phonemes in TTA03

\begin{tabular}{l|c|c|c|c|c|c|c}
\hline & 3 Moras & 4 Moras & \multicolumn{2}{|c|}{5 Moras } & 6 Moras & Total \\
\hline $\begin{array}{l}\text { ン(撥音) } \\
\text { A syllabic nasal }\end{array}$ & 3 & 4 & 4 & & - & - & 13 \\
\hline $\begin{array}{l}\text { (長音) } \\
\text { A prolonged sound }\end{array}$ & 3 & 3 & 3 & & & - & 12 \\
\hline $\begin{array}{l}\text { y(促音) } \\
\begin{array}{l}\text { A geminate } \\
\text { consonant }\end{array}\end{array}$ & 2 & 4 & 2 & & & 1 & 10 \\
\hline Total & 8 & 11 & \multicolumn{2}{|c|}{12} & 1 & 12 \\
\hline
\end{tabular}

The following features are common to all of the tests:

- the AJ-phonetic test play voice file of each word twice;

- order of questions for all words is random;

- learners solve problems in a new word order each time;

- voice was recorded and saved at $22 \mathrm{kHz}, 16 \mathrm{Bit}$;

- words were pronunced by a 30-year-old Tokyo native speaker and a university teacher of Japanese.

The words in each experiment were chosen so that learners can accurately judge and learn the accented listening ability without being disturbed by factors other than their listening ability. The detailed principle will be explained later. 


\section{Results}

From the instructor's perspective, the flow of the AJ-phonetic test was designed as shown in Figure 3.

\begin{tabular}{|c|c|c|c|c|c|c|}
\hline $\begin{array}{l}\text { 1) Words } \\
\text { selection and } \\
\text { recording }\end{array}$ & $\Rightarrow$ & $\begin{array}{l}\text { 2) Register } \\
\text { word in } \\
\text { database }\end{array}$ & $\Rightarrow$ & $\begin{array}{l}\text { 3) Create and } \\
\text { register a web } \\
\text { page for a } \\
\text { phonetic test }\end{array}$ & $\Rightarrow$ & $\begin{array}{l}\text { 4) Conduct } \\
\text { phonetic tests } \\
\text { on learners }\end{array}$ \\
\hline 仓 & & & & & & $\sqrt{ }$ \\
\hline $\begin{array}{l}\text { 8) } \\
\text { Troubleshooting } \\
\text { and } \\
\text { Compensation }\end{array}$ & • & $\begin{array}{l}\text { 7) Feedback } \\
\text { the results to } \\
\text { the learner and } \\
\text { end the } \\
\text { experiment }\end{array}$ & $\diamond$ & $\begin{array}{l}\text { 6) Analyzing } \\
\text { phonetic test } \\
\text { results }\end{array}$ & • & $\begin{array}{l}\text { 5) Phonetic test } \\
\text { results are } \\
\text { automatically } \\
\text { collected }\end{array}$ \\
\hline
\end{tabular}

Figure 3: The flow of the AJ-phonetic test from the instructor's perspective

Instructors have access to the results of students from their classes. In Figure 4, the class name is 'dsu' meaning Duksung Women's University. Besides, instructors can also view students results for a specific period (and download this data as an Excel file) or access test statistics. The latter is shown in Figure 5.

\section{$<$ Notice for Class manager > \\ Class name : dsu}

- 이 페이지는 수업(클래스) 관리자를 위한 페이지 입니다. 클래스에 소속된 학생들의 성적만 확인 할 수 있습니다. (このページは)

ラスの管理者の為のベージであります。クラスに所属されている学生の成儥げけを磪昭できます。)

- 관리자간 의사소통을 위한 게시판은 이 페이지에 작성 예정. 현재 작업중.

管理者間浬絡のための揭示板がのページに設ける予定。現在作用中。

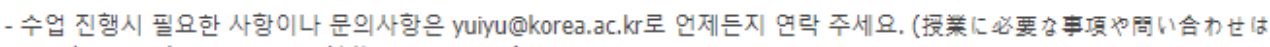
yuiyu@korea.ac.krまでいつでも遇絡して下さい。)

一管理したいクラスの変更はこちら $\rightarrow$ Change Class to manage

1. Simplified test result (시험 응시결과 간단 목록 | 試験結果の简単目録)

\begin{tabular}{|c|c|c|c|c|c|c|c|}
\hline Test & ID & Name & Date & Point & Point Percent & Status & Class \\
\hline TTA03 & gowoonii & 박고운 & 2013-06-23 오후 8:59:03 & 32 & 100.00 & Hand In & dsu \\
\hline TTA03 & gowoonii & 박고운 & 2013-06-23 오후 8:01:31 & 30 & 93.75 & Hand In & dsu \\
\hline TTA02 & gowoonii & 박고운 & 2013-06-23 오후 7:21:23 & 20 & 100.00 & Hand In & dsu \\
\hline TTAnn & ham-กาม & nITU $=L$ & 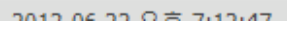 & 32 & 1 an $\mathrm{n}$ & Hand Th & da.. \\
\hline
\end{tabular}

Figure 4: Example of test results of the 'dsu' class (administrator page for instructors) 
1.1 Detail search and Download test result

(상세 시험 결과 검색 \& 엑셀 다운로드 | 詳しい試験絬果の検索とその結果をエクセルファイルにしてダウンロード)

Test Name :

User ID :

Period : Select Date $\sim$ Select Date

Search \& Excel Download for Researchers

(오픈시 경고는 무시해도 됩니다! / ファイルオープンの際して発生する敚告メッセージは無視して進んて下さい。)

* If you do not check any specific condition, you will get the total test result. But it will impose a heavy burden on Server.

So please check the condition, as you as possible.

(아무것도 체크하지 않으면 모든 테스트 결과를 출력합니다. 하지만, 서버에 부담이 큽니다. 가능하면 조건을 입력해 주세요.)

(何もチェックしないとすべのテスト絬果を出力します。しかし、サーパーの重理になります。出来れば条件を入力して下

さい。)

* 제출답안의 범례 $\rightarrow \mathbf{X}$ : 무응답 / $\mathbf{Y}:$ 악센트 있음 / $\mathbf{N}$ : 악센트 없음

*提出答察の凡例 $\rightarrow \mathbf{X}:$ 無応答/ $/ \mathbf{Y}:$ アクセント有 $/ \mathbf{N}:$ アクセント無

1.2. Statics of test (시험별 상세 통계 | 試験別、詳しい統計)

1.2.1. TTA00 (Test of Tokyo accent - 동경어 악센트 듣기 테스트(束京語アクセント聞き取りテスト) 00

\begin{tabular}{|c|c|c|c|}
\hline Test Name & Average & Hand In Number & Retired Number \\
\hline TTA00 & 84.53 & 1745 & 356 \\
\hline
\end{tabular}

1.2.2. TTA01 (Test of Tokyo accent - 동경어 악센트 듣기 테스트(束京語アクセント間き取りテスト) 01

\begin{tabular}{|c|c|c|c|}
\hline Test Name & Average & Hand In Number & Retired Number \\
\hline TTA01 & 76.70 & 2216 & 293 \\
\hline
\end{tabular}

1.2.3. TTA02 (Test of Tokyo accent - 동경어 악센트 듣기 테스트(束京語アクセント闌き取りテスト) 02

\begin{tabular}{|c|c|c|c|}
\hline Test Name & Average & Hand In Number & Retired Number \\
\hline TTA02 & 75.91 & 1926 & 157 \\
\hline 1.2.4. TTA03 (Test of Tokyo accent & - 동경어 악센트 듣기 테스트(東京語アクセント䦭き取りテスト) 03 \\
\hline TestName & Average & Hand In Number & Retired Number \\
\hline TTA03 & 61.76 & 2033 & 146 \\
\hline
\end{tabular}

Figure 5: Download of test results and test statistics (administrator page for instructor)

On the ther hand, the flow of the AJ-phonetic test from the test-taker's (learner's) perspective was designed as shown in Figure 6.

\begin{tabular}{|c|c|c|c|c|}
\hline $\begin{array}{l}\text { 1) Choose a phonetic } \\
\text { test to learn }\end{array}$ & $\Rightarrow$ & $\begin{array}{l}\text { 2) Conduct a phonetic } \\
\text { test }\end{array}$ & $\Rightarrow$ & $\begin{array}{l}\text { 3) Check phonetic test } \\
\text { results }\end{array}$ \\
\hline \multirow{3}{*}{ 仓 } & & $\mathbb{1}$ & & \multirow{3}{*}{ Л } \\
\hline & & $\begin{array}{l}\text { Communicate with } \\
\text { Instructors and Other } \\
\text { Learners }\end{array}$ & & \\
\hline & & $\mathbb{1}$ & & \\
\hline $\begin{array}{l}\text { 6) Analyzing and } \\
\text { reviewing the results } \\
\text { of the phonetic test }\end{array}$ & ڤ & $\begin{array}{l}\text { 5) Conduct a phonetic } \\
\text { test again }\end{array}$ & $\diamond$ & $\begin{array}{l}\text { 4) Analyzing and } \\
\text { reviewing the results } \\
\text { of the phonetic test }\end{array}$ \\
\hline
\end{tabular}

Figure 6: The flow of the experiment from learner's perspective 
The AJ-phonetic test makes it possible for a learner to check their results immediately after the test, an example of which is shown in Figure 7. The result page provides learners with their individual total scores and percentages, as well as average scores of all participants, in order that they can see their relative level rank and position in their class compared to the standard.

\author{
Result of "Phonetic Experiment \& Test" \\ ID : yuiyu Name : 유이유키 Test Name : Test of Tokyo accent Number of question : 40 \\ Total : 36 Point \\ Your percentage of correct answer : $90.00 \%$ \\ You and others, total average percentage of correct answer : $84.53 \%$ \\ Your hearing level : (Under construction function)
}

Thank you for your cooperation.

Test will be helpful to our research and you can prove your hearing skills, too. And You can check your test result at any time from [My Test Record] page of 'A $\mathrm{J}$

See you again.

\title{
Go back Do Test Main Go my test record page
}

Figure 7: Example of accent test results for learners

Learners also have access to a detailed history of data collecting, such as their progress and test results on the so-called My Test Record page (Figure 8), and further can review the tests that they have already completed (Figure 9). All these information enables them to identify their weaknesses such as accents that they need to work on more comprehensively, for example (Figure 10).

\section{< My Test Record - [A]-phonetic Test] >}

ID : yuiyu I Name : 유이유키 । Your organization : 大阪大学-同徳女子大学

\begin{abstract}
Go back, My test records home
1. Record of [י]Japanese phonetic Test \& Practice System 』 [AJ-phonetic Test]

$<$ Notice $>$

1) If you want to know the more information or detail result of the test, click the [Select] button in the below test-result list.

2) You can find detail information about the test you took. For example, you can check the correct answer and the answer you

handed in.

3) Moreover if you want listen the phonetics test you took one more time, please dick the [Hearing Start] button below. Test is
\end{abstract} absolutely same test you already took.

\begin{tabular}{|c|c|c|c|c|c|}
\hline Test Code & Test Date & Test Status & Point & Percent & Select \\
\hline TTA0O & 2019-08-09 오후 6:17:07 & Hand In & 36 & 90.00 & Select \\
\hline TTAnn & $301712320=11.10 \cdot 12$ & Dntirn & n & $n$ กn & Colner \\
\hline
\end{tabular}

Figure 8: Tests history of learner 
2. Shift graph of your [A] Phonetics test] point

2.1 Test of Tokyo accent - Test Code TTA00

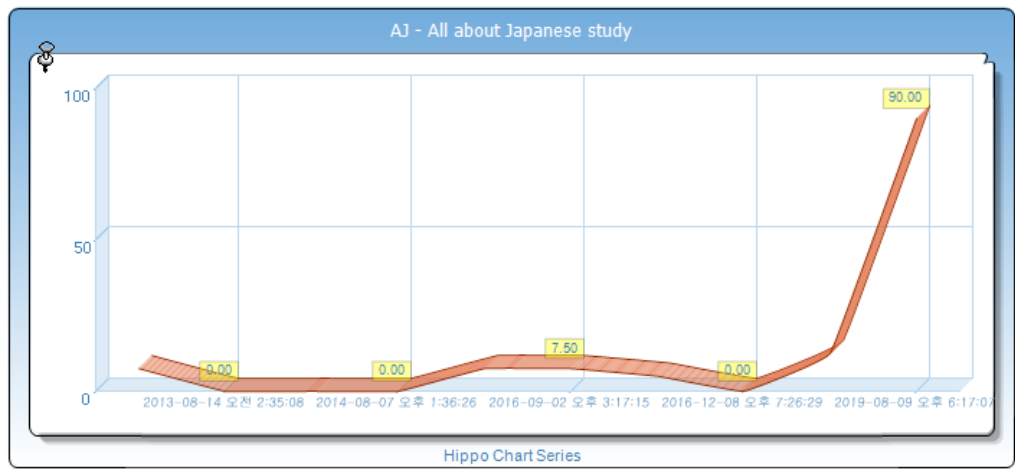

Figure 9: Progress based on test results visualized

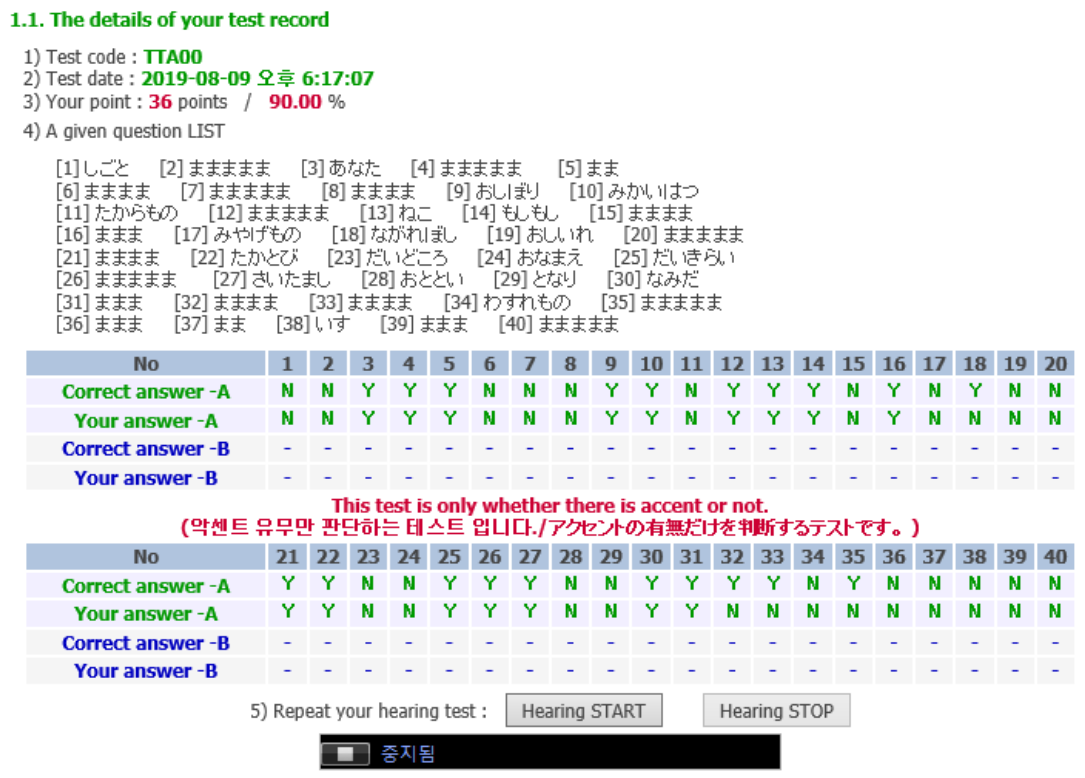

Figure 10: Details of test results

\subsection{Obtaining statictical data}

Functions of the administrator mode can be classified into three types. First, instructors can view the results and statistical data of individual learner's accent listening tests, as made available in detailed Excel files and on web pages. The administrator can also view necessary information about learners who participated in the test. It is also important to state that because the AJ-phonetic test can set administrator ID for each educational institution and class, several instructors and educational institutions can simultaneously conduct AJ-phonetic test experiment or education individually (Figures 4 and 5). 


\subsection{AJ-phonetic test and its benefits}

In Lee (1995), Lee et al. (1997), and Ayusawa (1997, 2000), Tokyo accent listening experiments were conducted for Japanese learners from various regions in Korea. The results showed that Japanese language learners differed in their ability to hear Japanese accents depending on their native language. However, this was an experiment in which the difficulty level of the test items was not adjusted in the experiment and analysis stages. In other words, an experimental design that divides the accentless pitch (the flat type) and the accent pitch (the relief type) is necessary for proper analysis.

\subsubsection{Comparison of accented and accentless words}

In case of the accentless words (the flat type), the correct answer rate is 50\%. However, accented words (those with a tone drop) are estimated to have $50 \%, 33.3 \%, 25 \%$, and $20 \%$ chances of being noted as correct, depending on the number of moras (2-5). Therefore, experimenting with accentless and accented words at the same time was avoided, as it may be confusing for learners. In this study, we added an experiment that clearly distinguished two types. (e.g. TTA00 vs TTA02)

\subsubsection{Comparison between accent pitches}

High numbers of moras in words are likely to increase the difficulty. At the same time it is known that longer words have a lower frequency of appearance. Therefore, in the AJ-phonetic test, dummy words were added to balance the number of moras, in order that learners can increase their learning effect. Because learners generally have a relatively small chance to encounter words with a large number of moras, they may develop a sense of accent by recognition and repetition exercises on dummy words.

Of course, dummy or meaningless words, such as 'まま' mama, in which a single note is listed consecutively have a disadvantage of being monotonous and easily accustomed to learners. However, the AJ Japanese Accent Test was designed with the primary objective of not only evaluating students' ability to recognize accents but also to develop a sense of accents in repeated practice. As emphasized in previous studies, Korean learners of Japanese with accentless native dialects, such as Seoul dialect, tend to listen to japanese through their native language system, which makes them ignore Japanese pitch.

As mentioned in Yang (2011, p. 71), accent education must be done before the wrong accent is fixed (early learning stage). And the experience of getting the right Japanese accent is more important than anything else. Repeated practice of consciously changing the height or listening to the pronunciation will be a useful learning strategy. Therefore, dummy words are suggested to be a good solution for improving this mora bias. 


\subsubsection{Intensive Test for Special phoneme}

Korean and Japanese have many similarities, however, the number of phonemes and syllables in Japanese is smaller than that of Korean. This acts as a barrier to Japanese language learning. In particular, Japanese speech and listening education is easy to be neglected and is easy to be biased towards grammar and reading.

As mentioned earlier, Japanese is moraic language. It is well-known that the concept of mora represents difficulties for Korean learners of Japanese because there are no special moraic phonemes in Korean. Therefore, training of such special phonemes as well as a thorough understanding of Japanese accent are urgently needed.

In this study, we designed an accent test that consists of words containing such moraic phonemes, a syllabic nasal 'ン' (撥音 hatsuon), a prolonged vowel sound '一' (長音 choon), and a geminate consonant “ッ' (促音 sokuon), in order for learners to adapt to special moraic phonemes. This study selected Japanese accent test words in consideration of the difficulty to recognize special moraic phonemes by Korean learners of Japanese.

\section{Analysis of the AJ-phonetic test results}

Finally, we will analyze test results submitted by the learners. For reference, test results can be reviewed directly at:

http://www.japanese.or.kr/phonetic_related_thesis.aspx.

\subsection{Answer ratio based on the number of moras in a word}

Table 5 presents results related to the difficulty levels provoked by the number of moras in a word.

Table 5: Difficulty level and the number of moras

\begin{tabular}{c|c|c}
\hline Moras & Level & Count \\
\hline 2 & 8.17 & 6 \\
3 & 7.75 & 20 \\
4 & 7.21 & 29 \\
5 & 6.94 & 36 \\
6 & 5 & 1 \\
\hline Average and sum & 7.26 & 92 \\
\hline
\end{tabular}

Results confirmed predictions, namely that words containing higher number of moras induce lower percentages of correct learners. (For reference, the AJ-phonetic 
test introduces a system that automatically changes the difficulty level depending on whether or not the word is correct. Also, it was found that the lower the level number, the higher the difficulty.)

We have thus decided to balance the number of moras in the accent test, and to add dummy words.

\subsection{The percentage of correct answers per test}

As expected, the TTA00 had the highest average score to determine the accent (see Figure 3).

Table 6: The percentage of correct answers per phonetic test

\begin{tabular}{l|l|l|l|l|l}
\hline Test & TTA00 & TTA01 & TTA02 & TTA03 & All \\
\hline Average & 86.31 & 80.59 & 79.33 & 69.21 & 76.43 \\
\hline
\end{tabular}

However, this study found some interesting results concerning the TTA01 and TTA02. First of all, TTA02 has accents on every word, and therefore it only is needed to find the accent location. However, in the case of TTA01, it is expected to be relatively difficult to solve because it is necessary to find the accent and the position of the accent at the same time. However, learners scored relatively high on TTA01, which was expected to be more difficult than TTA02. (Figure 3)

The reason for this result is that half of the words in TTA01 are words that have no accents, and therefore the correct probability of words that have no accents in TTA01 is evaluated at $50 \%$. However, the TTA02 which must accurately locate the accent has a less than $50 \%$ chance of getting an answer. It is essential in this respect to understand this distinction. Because it proves that the hypothesis of this study which designing a test by dividing the accentless pitch, and the accent pitch words are fairer and more accurate as a representation of what the learners understand in this case.

Also, given the difficulty of these tests, the instructor may suggest that learners perform accent exercises in the order of TTA00 - TTA01 - TTA02 - TTA03.

Finally, the learner was found to have the most difficulty in TTA03, which consists of words containing special moraic phonemes. It indicates that instructors should spend much time practicing accents on words that contain special moraic phonemes. The following sections discuss which of the special moraic phonemes represents most difficulties for Korean learners of Japanese. 


\subsection{Difficulty according to special moraic phonemes}

Words with either a syllabic nasal 'ン' (撥音 hatsuon), a prolonged vowel sound '一' (長音 choon), and a geminate consonant 'ッ’ (促音 sokuon) are included into the test TTA03, which contains 13, 12, and 10 items, respectively. For this reason, the average difficulty of each special phoneme is calculated as follows (see Figure 6). That is, the higher the number of moras, the higher the difficulty $(6.78 \rightarrow 6.27 \rightarrow 5.65 \rightarrow 5)$.

It was acknowledged that words containing a geminate consonant represent most difficulties to learners. Instructors of accent education are thus suggested to pay special attention to words including a geminate consonant.

Table 7: Difficulty level and special moraic phonemes

\begin{tabular}{|c|c|c|c|c|c|c|c|c|c|c|}
\hline & $3 \mathrm{M} / \mathrm{L}$ & $4 \mathrm{M} / \mathrm{L}$ & \multicolumn{6}{|c|}{$5 \mathrm{M} / \mathrm{L}$} & $6 \mathrm{M} / \mathrm{L}$ & Total/L \\
\hline $\begin{array}{l}\text { ン(撥音) } \\
\text { Syllabic nasal }\end{array}$ & $3 / 6.67$ & $4 / 6.5$ & $4 / 5.75$ & \multirow[b]{2}{*}{$2 / 5.5$} & - & & \multirow{3}{*}{$\begin{array}{l}1 / \\
6\end{array}$} & 7/5.71 & - & $13 / 6.29$ \\
\hline $\begin{array}{l}\text {-(長音) } \\
\text { Prolonged } \\
\text { sound }\end{array}$ & $3 / 6.67$ & $3 / 6.3$ & $3 / 5.67$ & & \multirow{2}{*}{$1 / 6$} & \multirow[t]{2}{*}{-} & & \multirow[t]{2}{*}{$6 / 5.67$} & - & $12 / 6.21$ \\
\hline $\begin{array}{l}\text { ツ(促音) } \\
\text { Geminate } \\
\text { consonant }\end{array}$ & $2 / 7$ & $4 / 6$ & $1 / 5$ & - & & & & & $1 / 5$ & $10 / 5.91$ \\
\hline Total/Level & $8 / 6.78$ & $11 / 6.27$ & \multicolumn{6}{|c|}{$12 / 5.65$} & $1 / 5$ & $32 / 5.93$ \\
\hline
\end{tabular}

\subsection{Test results by speakers of different Korean dialects}

Lee (1995) and Lee et al. (1997) conducted experiments with Japanese learners from Seoul and Busan through the same experiments as were used with Ayusawa et al. (2000). They reported that their Japanese accent listening scores were lower than those from Busan. Learners from Seoul who did not have high or low accents were less able to perceive high or low accents in Japanese, as compared to those learners from Busan who used high and low accents to distinguish meanings. Learners from Busan who speak dialects where high and low accents are involved in discrimination of meanings and learners from Seoul who use dialects where high and low accents are not involved in discrimination of meaning are different in their ability to perceive high and low accents in Japanese. It was thus verified that the difference depends on the presence or absence of high and low accents on the mower.

In other words, Japanese learning could be influenced by local dialects, and by the presence or absence of a distinctive tone drop in them. This study verified this point and conducted a detailed comparison between Korean learners of Japanese from 
Gyeongsang-do and Jeonla-do regions respectively. Both regions employ pitch accent dialects.

Table 8: Test results and their difference by region

\begin{tabular}{lcccccc}
\hline \multirow{2}{*}{ Region } & No. of participants & \multicolumn{5}{c}{ Average } \\
\cline { 3 - 7 } & & TTA00 & TTA01 & TTA02 & TTA03 & ALL \\
\hline Seoul & 234 & 80.00 & 76.81 & 76.25 & 63.54 & $\mathbf{7 4 . 1 6}$ \\
Gyeonggi-do & 111 & 83.46 & 74.63 & 75.69 & 69.21 & 75.76 \\
Chungcheong-do & 11 & 86.11 & 78.63 & 61.50 & 51.44 & 64.07 \\
Gyeongsang-do & 24 & 85.41 & 80.55 & 75.88 & 69.35 & $\mathbf{7 8 . 5 1}$ \\
Jeonla-do & 6 & 86.96 & 91.18 & 83.93 & 73.27 & $\mathbf{8 4 . 1 1}$ \\
\hline
\end{tabular}

*Note: Gangwon-do region was excluded from the comparison due to the lack of data (2 participants only).

Through the results of this study, it was confirmed that learners of Gyeongsang-do and Jeonla-do, in whose native dialects relatively strong tones or accents are detected, perform better on Japanese accent tests, which was already shown in previous studies. However, no comparative studies have yet been conducted on perception of Japanese accents among speakers of Gyeongsang-do and Jeonla-do regions. This longitudinal study gathered and analyzed a large amount of data to find that Koreans whose native dialect is that of Jeonla-do region performed better than those of Gyeongsang-do region dialect in all accent tests.

\section{Conclusions}

In this paper, we divided subjects participating in e-learning into instructors and learners, and conducted the AJ-phonetic test. Through the LMS system, instructors were able to access academic performance information of learners, their history and results obtained through the AJ-phonetic test. All these information enabled instructors to provide each learner with an appropriate feedback, which further helped learners to develop new strategies for learning. Since learners took the AJ-phonetic test online, results were immediately available to both instructors and learners. Such information allow learners to check their learning progress and achievements, and offers an objective analysis as to how well they learn Japanese language.

This study conducted the Tokyo accent test (the AJ-phonetic test) to verify the following hypothesis empirically.

First of all, when preparing accent tests, we needed to make a separate set of words because the accentless pitch and the accent pitch represent different levels of difficulty for korean learners of Japanese. Secondly, as the presence or absence of special moras affects the difficulty in the test, we added dummy words to control the 
level of difficulty and increase the learning effect of the test. Thirdly, since Korean learners of Japanese have difficulty recognizing accents of words containing special moras, it was necessary to pay additional attention to the practice of accents of such words. Finally, Korean learners of Japanese differ in their ability to recognize Japanese accents depending on their native dialect. All these findings bring us to conclusion that it is necessary to provide Japanese accent education based on thorough information about a learner (native language, language education etc.) as well as theory on Japanese accent and its learning and teaching. Last but not least, the AJ-phonetic test was designed as part of a computer-enabled Japanese class in a way to suit learner's individual schedule; it is available anytime and anyplace.

For further studies, we plan to add new accent tests with new experimental stimuli, which would include additional words with special moraic phonemes and different dummy words. However, prior to such work, we would like to further consolidate the analysis of the test contents currently available. We therefore plan to upgrade the system based on the advice received, such as those concerning types of data required by instructors and methods of analysis, as well as types of feedback material and methods of presentation to learners.

\section{References}

Ayusawa, T. (1997). Tokyogo akusento no kikitori tesuto ni tsuite [About Tokyo Accent Perception test], Spoken Japanese language education: looking to the 21st century, 18920, The National Language Research Institute.

Ayusawa, T., Nishinuma, Y., \& Kawatsu, M. (2000). Akusento shutoku no odankenkyu sannenhan no chousakekka - [Longitudinal study of accent acquisition: Survey results for three and a half years-]. Proceedings of the 14th Annual Conference of the Phonetic Society of Japan, 177-182.

Choi, J. (2006). Ilbono accentheki wichibyonhwae kanhan ilgochal [Investigation on the acceptability of Japanese prosody -the effect of the position of accent nuclei-]. Journal of Japanese Language and Literature, 58(1), 187-204.

Choi, J., \& Kim, Y. (2008). Iraninggu wo katsuyosita Nihongo akusento kikitori renshu maruchimediajyugyo deno katsuyo wo chusin ni [Japanese Accent Perception Test based on e-learning: Using tool to improve the skill of accent perception based on multimedia technology]. Journal of Japanese language and literature, 64, 263-279.

Jeong, S. (2009). Souru hougenwo bogotosuru nihongo gakushushano nihongo akusentono seisito chikaku [Generation and Perception of Japanese Accents of Japanese Learners with Seoul direct]. Journal of Japanese language Association of Korea, 26, 217-234.

Lee, M. (1995). Kankokujin gakushusha no tokyogo akusento no chikaku - souru chiho no baai [Perception of Korean accent by Korean learners; In the case of Seoul region]. Proceedings of the 1995 Japanese Language Education Society Fall Conference, 159-164.

Lee, M., Ayusawa, T., \& Kim, S. (1997). Kankokugowasha no "tokyogo akusento kikitori tesuto" no kekka - Souru, Pusan, Koushu hougenwasha no baai [Results of the "Tokyo Accent 
Listening Test" by Korean native speakers: In the case of Seoul, Busan, and Gwangju dialect speakers]. Toward 21st Century Japanese Speech Education, 22-30.

Lee, M. (2002). A Study on the development of web-based learning model and the effect of feedback type for Japanese language listening comprehension (doctoral dissertation). Pusan University.

Rosenberg, M. J. (2001). E-learning: Strategies for delivering knowledge in the digital age. New York: McGraw-Hill.

Ogawara, Y. (1997). Hatsuon kousei bamen ni okeru gakushusha no hatsuon to kikitori nokankei ni tsuite [The relation between learners' pronunciation and listening in pronunciation correction situations]. Journal of Japanese language teaching, 92, 10-52.

Onzuka, C. (2011). Kankokugo bogowashaniokeru tokushuonso no ninshiki - onin ninshiki tohyoki: riron to jikkenkara no apoorochi [The Phonological Awareness of the Japanese Special Phoneme by the Korean Native Speakers - The Phonological Awareness and The Notation: An Approach from a Theory and an Experiment-]. Journal of Japanese Language and Literature, $77(1)$.

Yang, N. (2011). Seoul banonhwajawa jeonnam bangonhwajarul desanguro han ilbono accent chonchi gyonghyang bigyo [Japanese accent hearing trend comparison having made to Seoul dialect speaker and Jeonnam dialect speaker]. Journal of Japanese Language Education Association, 56, 49-72. 